\section{TINJAUAN HUKUM KETENAGAKERJAAN TENTANG PERLINDUNGAN BURUH/PEKERJA BERDASARKAN UNDANG-UNDANG NOMOR 13 TAHUN 2003 ${ }^{1}$ \\ Oleh : Mario Lawendatu ${ }^{2}$ \\ Deasy Soewikromo ${ }^{3}$ Revy S. M. Korah ${ }^{4}$}

\section{ABSTRAK}

Tujuan dilakukannya peneltian ini adalah untuk mengetahui bagaimana hakikat, sifat, prinsip dan objek perlindungan buruh/tenaga kerja dan bagaimana bentuk hukum ketenagakerjaan terhadap perlindungan buruh berdasarkan Undang-Undang Nomor 13 Tahun 2003. Dengan menggunakan metode penelitian yuridis normatif, disimpulkan: 1 . Hakikat hukum ketenagakerjaan merupakan perlindungan terhadap tenaga kerja, untuk menjamin hakhak dasar pekerja/buruh dan menjamin kesamaan kesempatan serta perlakuan tanpa diskriminasi atas dasar apapun untuk mewujudkan kesejahteraan pekerja/buruh dan keluarganya dengan tetap memperhatikan perkembangan dunia usaha. Sifat perlindungan buruh tenaga kerja untuk mengatur hubungan kerja antara tenaga kerja dan pengusaha dan bersifat privat (perdata). Dalam UndangUndang Nomor 13 Tahun 2003 tentang ketenagakerjaan mengandung prinsip perlindungan tenaga kerja antara lain perlindungan atas hak-hak dalam hubungan kerja, perlindungan keselamatan dan kesehatan kerja, perlindungan khusus bagi pekerja/buruh perempuan, anak penyandang cacat dan perlindungan kesejahteraan dan jaminan sosial. Sedangkan Objek perlindungan tenaga kerja menurut Undang-Undang Nomor 13 Tahun 2003 meliputi: a. Perlindungan atas hak-hak dalam hubungan kerja. b. Perlindungan atas hak-hak dasar pekerja/buruh untuk berunding dengan pengusaha dan mogok kerja. c. Perlindungan keselamatan dan kesehatan kerja. d. Perlindungan khusus bagi pekerja/buruh perempuan, anak dan penyandang cacat. e. Perlindungan tentang upah, kesejahteraan, dan jaminan sosial tenaga kerja dan $\mathrm{f}$. Perlindungan

\footnotetext{
${ }^{1}$ Artikel Skripsi

2 Mahasiswa pada Fakultas Hukum Unsrat, NIM 15071101544

3 Fakultas Hukum Unsrat, Doktor Ilmu Hukum

${ }^{4}$ Fakultas Hukum Unsrat, Magister Ilmu Hukum
}

atas hak pemutusan hubungan tenaga kerja. 2 . Perlindungan hukum terhadap buruh/pekerja mencakup antara lain: keselamatan dan kesehatan kerja, perlindungan pekerja atau buruh perempuan, anak dan penyandang cacat. perlindungan upah, perlindungan hak.

Kata kunci: Tinjauan Hukum, Ketenagakerjaan, Perlindungan buruh/Pekerja

\section{PENDAHULUAN}

\section{A. Latar Belakang}

Perlindungan pekerja dapat dilakukan, baik dengan jalan memberikan tuntunan, maupun dengan jalan meningkatkan pengakuan hak-hak asasi manusia, perlindungan fisik dan teknis serta sosial dan ekonomi melalui norma yang berlaku dalam lingkungan kerja itu.

Secara normatif, UUD 1945 menjamin hak setiap warganegara untuk memperoleh pekerjaan (pasal 27 ayat 2). Hal ini dipertegas kembali dalam UUD Negara Republik Indonesia Tahun 1945 (hasil amandemen kedua) Bab XA tentang Hak Asasi Manusia ( Pasal 38 A-28J ). Pasal 28 D mengamanatkan bahwa " setiap orang berhak untuk bekerja serta mendapat imbalan dan perlakuan yang adil dan layak dalam hubungan kerja ". Selanjutnya dalam Pasal 28 I ayat 4 menegaskan bahwa perlindungan (protection), pemajuan (furtherance), penegakan (enforcement), dan pemenuhan (fulfilment) hak asasi manusia adalah tanggung jawab negara terutama pemerintah. ${ }^{5}$ Sebelumnya pemerintah telah menetapkan 38 ayat 2 menyebutkan "setiap orang berhak dengan bebas memilih pekerjaan yang disukainya dan berhak pula atas syaratsyarat ketenagakerjaan yang adil ". Sedangkan, dalam pasal 71 , mengatur mengenai tanggung jawab pemerintah untuk menghormati, melindungi, menegakkan, dan memajukan hak asasi manusia baik yang diatur dalam undangundang, maupun hukum internasional. ${ }^{6}$

Setiap manusia selalu membutuhkan biaya untuk memenuhi kebutuhan hidupnya. Untuk mendapatkan biaya hidup seseorang perlu bekerja. Bekerja dapat dilakukan secara mandiri atau bekerja kepada orang lain. Bekerja kepada orang lain dapat dilakukan dengan bekerja kepada negara yang selanjutnya disebut

\footnotetext{
5 Lalu Husni, Pengantar Hukum Ketenagakerjaan Indonesia, PT. RajaGrafindo, Jakarta, 2010, hal 11.

6 Ibid, hal 11
} 
sebagai pegawai atau bekerja kepada orang lain (swasta) yang disebut sebagai buruh atau pekerja. Setiap tenaga kerja berhak dan mempunyai kesempatan yang sama untuk memperoleh pekerjaan dan penghidupan yang layak tanpa membedakan jenis kelamin, suku, ras, agama, dan aliran politik sesuai dengan minat dan kemampuan tenaga kerja yang bersangkutan, termasuk perlakuan yang sama terhadap para penyandang cacat sehingga secara yuridis perlu diberikan perlindungan dan setiap pengusaha wajib untuk memberikan hak dan kewajiban kepada tenaga kerja tanpa membedakan jenis kelamin, suku, ras ,agama warna kulit dan aliran politik. Karena itu dalam pasal 4 huruf c Undang-Undang Nomor 13 Tahun 2003 tentang Ketenagakerjaan secara tegas menyatakan, bahwa salah satu tujuan pembangunan ketenagakerjaan adalah memberikan perlindungan kepada tenaga kerja dalam mewujudkan kesejahteraan. ${ }^{7}$

Dengan demikian, perlindungan tenaga kerja sangat mendapat perhatian dalam hukum ketenagakerjaan karena dalam asas pemberlakuan ketentuan ketenagakerjaan disebutkan semua ketentuan ketenagakerjaan berlaku terhadap semua pekerja tanpa membedakan statusnya. Untuk itulah penulis tertarik untuk membahas dalam tulisan karya ilmiah skripsi ini dengan judul " Tinjauan hukum ketenagakerjaan terhadap perlindungan buruh berdasarkan Undang-Undang Nomor 13 Tahun 2003".

\section{B. Perumusan Masalah}

1. Bagaimanakah hakikat, sifat, prinsip dan objek perlindungan buruh/tenaga kerja?

2. Bagaimanakah bentuk hukum ketenagakerjaan terhadap perlindungan buruh berdasarkan Undang-Undang Nomor 13 Tahun 2003?

\section{Metode Penelitian}

"Penelitian ini merupakan bagian dari penelitian hukum kepustakaan yakni dengan cara meneliti bahan pustaka atau yang

\footnotetext{
7 Lihat, UU No 13 Tahun 2013 pasal 4 huruf c.
}

dinamakan penelitian hukum normatif". ${ }^{8}$ Maka dalam penelitian ini penulis menggunakan metode-metode sebagai berikut :

1. Metode Kepustakaan (Library Research), yakni suatu metode yang digunakan dengan jalan mempelajari buku-buku literatur, perundang-undangan, putusan pengadilan dan yurisprudensi, bahanbahan lainnya dalam majalah dan surat kabar, yang berkaitan dengan materi pokok yang kemudian digunakan untuk mendukung pembahasan skripsi.

2. Metode Komparasi (Comparative Research), yakni suatu metode yang digunakan dengan jalan mengadakan perbandingan antara pendapat atau teori dari ahli hukum yang satu dengan ahli hukum yang lain untuk mendapatkan kesimpulan-kesimpulan guna mendukung pembahasan skripsi.

Kedua metode dan teknik pengolahan data tersebut diatas, dilakukan secara bergantigantian bilamana perlu untuk mendukung pembahasan skripsi ini.

\section{PEMBAHASAN}

\section{A. Hakikat, Tujuan, Prinsip Hukum Ketenagakerjaan Dan Objek Perlindungan Tenaga Kerja}

Hakikat hukum ketenagakerjaan adalah perlindungan terhadap tenaga kerja, yakni dimaksudkan untuk menjamin hak-hak dasar pekerja/buruh dan kesamaan kesempatan serta perlakuan tanpa diskriminasi atas dasar apapun untuk mewujudkan kesejahteraan pekerja/buruh dan keluarganya dengan tetap memperhatikan perkembangan kemajuan dunia usaha. Landasan idiil pembangunan ketenagakerjaan berlandaskan Pancasila dan landasan konstitusionilnya adalah UndangUndang Negara Republik Indonesia Tahun 1945. Pembangunan ketenagakerjaan dilaksanakan dalam rangka pembangunan manusia Indonesia seutuhnya. Oleh sebab itu, pembangunan ketenagakerjaan dilaksanakan untuk mewujudkan manusia dan masyarakat Indonesia yang sejahtera, adil, makmur dan merata baik materriil maupun spiritual.

\footnotetext{
8 Soerjono Soekanto dan Sri Mamudji, Penelitian Hukum Normatif Suatu Tinjauan Singkat, PT RajaGrafindo
} Persada, Jakarta,2004, hal 13. 
Asas pembanguanan ketenagakerjaan diselenggarakan berdasarkan atas keterpaduan dengan koordinasi fungsional lintas sektoral pusat dan daerah-daerah, artinya asas pembangunan ketenagakerjaan pada dasarnya sesuai dengan asas pembangunan nasional, khususnya asas demokrasi Pancasila serta asas adil dan merata. Pembangunan ketenagakerjaan mempunyai banyak dimensi dan keterkaitan dengan berbagai pihak yaitu antara pemerintah, pengusaha dan pekerja/buruh. Oleh sebab itu, pembangunan ketenagakerjaan dilaksanakan secara terpadu dalam bentuk kerja sama yang saling mendukung.

\section{B. Tinjauan hukum ketenagakerjaan tentang perlindungan buruh/pekerja berdasarkan undang-undang nomor 13 tahun 2003}

\section{Keselamatan dan Kesehatan Kerja.}

Dalam Pasal 86 ayat 1 Undang-Undang Nomor 13 Tahun 2003 disebutkan bahwa setiap pekerja/buruh mempunyai hak untuk memperoleh perlindungan atas :

a. keselamatan dan kesehatan kerja

b. moral dan kesusilaan dan

c. perlakuan yang sesuai dengan harkat dan martabat manusia serta nilai-nilai agama

Untuk melindungi keselamatan pekerja/buruh guna mewujudkan produktivitas kerja yang optimal diselenggarakan upaya keselamatan dan kesehatan kerja. Perlindungan tersebut dilaksanakan sesuai dengan peraturan perundang-undangan yang berlaku. Untuk mewujudkan perlindungan keselamatan kerja, maka pemerintah telah melakukan upaya pembinaan norma di bidang ketenagakerjaan. Dalam pengertian pembinaan norma ini sudah mencakup pengertian pembentukan, penerapan dan pengawasan norma itu sendiri.

Atas dasar itu dikeluarkanlah UndangUndang Nomor 1 Tahun 1970 tentang Keselamatan Kerja, sebagai pengganti peraturan di bidang keselamatan kerja yang telah ada sebelumnya yaitu Veilegheids Reglement Stbl Nomor 406 Tahun 1910, yang dinilai sudah tidak sesuai lagi dengan kemajuan dan perkembangan masalah ketenagakerjaan. ${ }^{9}$. Walaupun namanya undang - undang tentang

\footnotetext{
9 opcit, hal 148
}

keselamatan kerja, namun cakupan materinya termasuk pula masalah kesehatan kerja, karena keduanya tidak dapat dipisahkan, jika keselamatan kerja sudah terlaksana dengan baik maka kesehatan kerjapun akan tercapai.

\section{Perlindungan pekerja/buruh perempuan, anak dan penyandang cacat.}

a. Perlindungan pekerja/buruh perempuan

- Pengusaha dilarang mempekerjakan antara pukul 23.00 sampai dengan 07.00 terhadap pekerja/buruh perempuan yang berumur kurang dari delapan belas tahun (Pasal 76 ayat 1).

- Pengusaha dilarang mempekerjakan pekerja/buruh perempuan hamil yang menurut keterangan dokter berbahaya, baik bagi kesehatan dan keselamatan kandungannya maupun dirinya apabila bekerja antara pukul 23.00 sampai dengan 07.00 (Pasal 76 ayat 2).

- Pengusaha yang mempekerjakan pekerja/ buruh perempuan antara pukul 23.00 sampai dengan 07.00 (Pasal 76 ayat 3 ) wajib ; memberikan makanan dan minuman bergizi dan menjaga kesusilaan dan keamanan selama di tempat kerja.

- Pengusaha wajib menyediakan angkutan antar jemput bagi pekerja/buruh perempuan yang berangkat dan pulang bekerja antara pukul 23.00 sampai dengan 05.00 (Pasal 76 ayat 4 ).

- Pekerja/buruh perempuan yang dalam masa haid merasakan sakit dan memberitahukan kepada pengusaha, tidak wajib bekerja pada hari pertama dan kedua pada waktu haid (Pasal 81 ayat 1 Undang-Undang Nomor 13 Tahun 2003.

- Pekerja/buruh perempuan berhak memperoleh istirahat selama 1,5 bulan sebelum saatnya melahirkan anak dan 1,5 bulan sesudah melahirkan menurut perhitungan dokter kandungan atau bidan (Pasal 82 ayat 1 Undang-Undang Nomor 13 Tahun 2003).

- Pekerja/buruh perempuan yang mengalami keguguran kandungan 
berhak memperoleh istirahat 1,5 bulan atau sesuai perhitungan dokter kandungan atau bidan (Pasal 82 ayat 2 Undang-Undang Nomor 13 Tahun 2003.

- Pekerja/buruh perempuan yang anaknya masih menyusui harus diberikan kesempatan sepatutnya untuk menyusui anaknya jika hal itu harus dilakukan selama waktu kerja ( Pasal 83 Undang-Undang Nomor 13 Tahun 2003.

\section{Program Jaminan Sosial Tenaga Kerja}

Pengertian Jaminan Sosial Tenaga Kerja (Jamsostek) menurut ketentuan Pasal 1 ayat 1 Undang-Undang Nomor 3 Tahun 1992 adalah suatu perlindungan bagi tenaga kerja dalam bentuk santunan berupa uang sebagai pengganti sebagian dari penghasilan yang hilang atau berkurang dan pelayanan sebagai akibat peristiwa atau keadaan yang dialami oleh tenaga kerja berupa kecelakaan kerja, sakit, bersalin, hari tua dan meninggal dunia.

Berdasarkan uraian diatas jelas bahwa program Jaminan Sosial Tenaga Kerja merupakan bentuk perlindungan ekonomis dan perlindungan sosial. Dikatakan demikian karena program ini memberikan perlindungan dalam bentuk santunan berupa uang atas berkurangnya penghasilan dan perlindungan dalam bentuk pelayanan perawatan/pengobatan pada saat seorang pekerja tertimpa risiko-risiko tertentu.

Program Jamsostek merupakan kelanjutan program Asuransi Sosial Tenaga Kerja (ASTEK) yang didirikan menurut Peraturan Pemerintah Nomor 33 Tahun 1977. Secara yuridis penyelenggaraan program Jamsostek dimaksudkan sebagai pelaksanaan Pasal 10 dan Pasal 15 Undang-Undang Nomor 14 Tahun 1969 tentang Ketentuan-Ketentuan Pokok mengenai Tenaga Kerja yang sekarang sudah dicabut dan diganti dengan Undang - Undang Nomor 13 Tahun 2003 tentang Ketenagakerjaan.

Sejalan dengan Undang - Undang Nomor 40 Tahun 2004 tentang Sistem Jaminan Sosial Nasional, maka PT Jamsostek (Persero), PT Askes (Persero), PT Taspen (Persero), dan Asabri (Persero), ditetapkan sebagai badan penyelenggara jaminan sosial, dan wajib menyesuaikan prinsip-prinsip penyelenggaraan Sistem Sosial Nasional paling lama lima tahun sejak undang-undang diundangkan. Jenis program jaminan sosial menurut UndangUndang Nomor 40 Tahun 2004 mencakup lima program, yaitu Jaminan Kesehatan, Jaminan Hari Tua, Jaminan Pensiun dan Jaminan Kematian.

\section{Perlindungan Upah.}

Pengupahan termasuk sebagai salah satu aspek penting dalam perlindungan pekerja/buruh. Hal ini secara tegas diamanatkan pada Pasal 88 ayat 1 UndangUndang Nomor 13 Tahun 2003 bahwa setiap pekerja/ buruh berhak memperoleh penghasilan yang memenuhi penghidupan yang layak bagi kemanusiaan. Maksud dari penghidupan yang layak, dimana jumlah pendapatan pekerja/buruh dari hasil pekerjaannya mampu untuk memenuhi kebutuhan hidup pekerja/buruh dan keluarganya secara wajar, yang meliputi makanan dan minuman, sandang, perumahan, pendidikan, kesehatan, rekreasi, dan jaminan hari tua.

Motivasi utama seorang pekerja/buruh bekerja di perusahaan adalah mendapatkan nafkah, dan upah merupakan hak bagi pekerja/buruh yang bersifat sensitif. Karenanya, tidak jarang pengupahan menimbulkan perselisihan.

Beberapa aturan tentang pengupahan pekerja/buruh dapat dirankum sebagai berikut:

\section{a. Asas Pengupahan}

1. Hak menerima upah timbul pada saat adanya hubungan kerja dan berakhir pada saat hubungan kerja putus ( Pasal 2 Peraturan Pemerintah Nomor 8 Tahun 1981 tentang Perlindungan Upah).

2. Pengusaha tidak boleh mengadakan diskriminasi upah bagi pekerja/buruh laki-laki dan wanita untuk jenis pekerjaan yang sama ( Pasal 3 Peraturan Pemerintah Nomor 8 Tahun 1981 tentang Perlindungan Upah).

3. Setiap pengusaha wajib melaksanakan ketentuan waktu kerja ( Pasal 77 ayat 1 Undang-Undang Nomor 13 Tahun 2003 tentang Ketenagakerjaan). 
4. Pengusaha yang mempekerjakan pekerja/buruh melebihi waktu kerja sebagaimana dimaksud dalam ayat 1 wajib membayar upah kerja lembur ( Pasal 78 ayat 2 Undang-Undang Nomor 13 Tahun 2003 tentang Ketenagakerjaan).

5. Pengusaha yang mempekerjakan pekerja/buruh melakukan pekerjaan pada hari libur resmi sebagaimana dimaksud dalam ayat 2 wajib membayar upah kerja lembur ( Pasal 85 ayat 3 Undang-Undang Nomor 13 Tahun 2003 tentang Ketenagakerjaan).

6. Pengusaha dilarang membayar upah lebih rendah dari ketentuan upah minimum ( Pasal 90 ayat 1 UndangUndang Nomor 13 Tahun 2003).

7. Upah tidak di bayar apabila pekerja/buruh tidak melakukan pekerjaan ( Pasal 93 ayat 1 UndangUndang Nomor 13 Tahun 2003).

8. Komponen upah terdiri dari upah pokok dan tunjangan tetap, dengan formulasi upah pokok minimal $75 \%$ dari jumlah upah pokok dan tunjangan tetap (Pasal 94 Undang-Undang Nomor 13 Tahun 2003).

9. Pelanggaran yang dilakukan oleh pekerja/buruh karena kesengajaan atau kelalaiannya dapat dikenakan denda ( Pasal 95 ayat 1 Undang-Undang Nomor 13 Tahun 2003).

10. Pengusaha yang karena kesengajaannya atau kelalaiannya mengakibatkan keterlambatan pembayaran upah, dikenakan denda sesuai dengan persentase tertentu dari upah pekerja/buruh ( Pasal 95 ayat 2 Undang-Undang Nomor 13 Tahun 2003).

11. Dalam hal perusahaan dinyatakan pailit atau dilikuidasi berdasarkan peraturan perundang-undangan yang berlaku, maka upah dan hak-hak lainnya dari pekerja/buruh merupakan utang yang didahulukan pembayarannya ( Pasal 95 ayat 4 Undang-Undang Nomor 13 Tahun 2003)

12. Tuntutan pembayaran upah pekerja/buruh dan segala pembayaran yang timbul dari hubungan kerja menjadi kedaluwarsa setelah melampaui jangka waktu dua tahun sejak timbulnya hak ( Pasal 96 UndangUndang Nomor 13 Tahun 2003).

\section{b. Bentuk Upah}

Yang dimaksud upah adalah :

1. Hak pekerja/buruh yang diterima dan dinyatakan dalam bentuk uang sebagai imbalan dari penngusaha atau pemberi kerja kepada pekerja/buruh yang ditetapkan dan dibayarkan menurut suatu perjanjiaan kerja, kesepakatan, atau peraturan perundang-undangan, termasuk tunjangan bagi pekerja/buruh dan keluarganya atas suatu pekerjaan dan/atau jasa yang telah atau akan dilakukan (Pasal 30 Undang-Undang Nomor 13 Tahun 2003).

2. Suatu penerimaan sebagai imbalan dari pengusaha kepada buruh untuk sesuatu pekerjaan atau jasa yang telah dilakukan atau akan dilakukan, dinyatakan atau dinilai dalam bentuk uang yang ditetapkan menurut suatu persetujuan atau peraturan perundang-undangan, dan dibayarkan atas dasar suatu perjanjian kerja antara pengusaha dengan buruh, termasuk tunjangan, baik untuk buruh sendiri maupun keluarganya ( Pasal 1 huruf a Peraturan Pemerintah Nomor 8 Tahun 1981).

Dari uraian di atas jelas upah diberikan dalam bentuk uang, namun secara normatif masih ada kelonggaran bahwa upah dapat diberikan dalam bemtuk lain berdasarkan perjanjian atau peraturan perundangan, dengan batasan nilainya tidak boleh melebihi $25 \%$ dari nilai upah yang seharusnya diterima ( Pasal 12 Peraturan Pemerintah Nomor 8 Tahun 1981).

\section{c. Upah Minimum}

Berdasarkan ketentuan Pasal 1 ayat 1 Peraturan Menteri Tenaga Kerja Nomor Per01/Men/1999 tentang Upah Minimum, pengertian upah minimum adalah upah bulanan terendah yang terdiri atas upah pokok termasuk tunjangan tetap.

Berdasarkan Peraturan Menteri Tenaga Kerja Nomor Per-01/Men/1999 jo Keputusan Menteri Tenaga Kerja dan Transmigrasi Nomor Kep-226/Men/2000 
jangkaun wilayah berlakunya upah minimum meliputi :

1. Upah Minimum Provinsi (UMP) berlaku di seluruh kabupaten/kota dalam satu wilayah provinsi;

2. Upah Minimum Kabupaten/Kota(UMK) berlaku dalam satu wilayah kabupaten/kota.

Sejalan dengan kewenangan otonomi daerah mekanisme penetapan upah minimum juga mengalami perubahan secara sifnifikan yang ditetapkan oleh Gubernur ;

a. Upah Minimum Provinsi (UMP)/Upah Minimum Kabupaten/Kota(UMK) berdasarkan usulan Komisi Penelitian Pengupahan dan Jaminan Sosial Dewan Ketenagakerjaan Daerah melalui Kanwil Depnaker setempat.

b. Upah Minimum Sektoral Provinsi (UMSP)/Upah Minimum Sektoral Kabupaten/Kota (UMSK) atas kesepakatan organisasi pengusaha dan serikat pekerja/serikat buruh.

Penetapan upah minimum dilakukan dengan mempertimbangkan (Pasal 6 Peraturan Menteri Tenaga Kerja Nomor Per01/Men/1999) :

a. Kebutuhan Hidup Minimum (KHM).

b. Indeks Harga Konsumen (IHK).

c. Kemampuan, perkembangan dan kelangsungan perusahaan

d. Upah pada umumnya berlaku di daerah tertentu dan antar daerah.

e. Kondisi pasar kerja.

f. Tingkat perkembangan perekonomian dan pendapatan perkapita.

\section{Perlindungan atas hak-hak dasar pekerja/buruh untuk berunding dengan pengusaha dan mogok kerja.}

Menurut Pasal 1 angka 23 Undang - Undang Nomor 13 Tahun 2003 menyebutkan mogok kerja adalah tindakan pekerja/buruh yang direncanakan dan dilaksanakan secara bersama-sama dan/atau oleh serikat pekerja/buruh/serikat buruh untuk menghentikan atau memperlambat pekerjaan.

Pada prinsipnya mogok kerja (strike) merupakan hak dasar pekerja/buruh dan serikat pekerja/buruh dilakukan secara sah, tertib, dan damai sebagai akibat gagalnya perundingan seperti yang tercantum dalam
Pasal 137 Undang-Undang Nomor 13 Tahun 2003. Yang dimaksud dengan gagalnya perundingan adalah tidak tercapainya kesepakatan penyelesaian perselisihan hubungan industrial yang dapat disebabkan karena salah satu pihak tidak mau melakukan perundingan atau perundingan mengalami jalan buntu. Pengertian tertib dan damai disini adalah tidak mengganggu keamanan dan ketertiban umum , dan/atau mengancam keselamatan jiwa dan harta benda perusahaan atau pengusaha atau orang lain atau milik masyarakat. Sedangkan penutupan perusahaan (lock out) merupakan hak dasar pengusaha untuk menolak pekerja/buruh sebagian atau seluruhnya untuk menjalankan pekerjaan sebagai akibat gagalnya perundingan seperti yang dinyatakan dalam pasal 146 ayat 1 Undang-Undang Nomor 13 Tahun 2003.

Secara yuridis walaupun pemogokan dan penutupan perusahaan merupakan hak dasar, dalam melakukan tindakan tersebut para pihak tetap harus menaati ketentuan perundang undangan. Dengan demikian, para pihak tidak dapat menggunakan haknya sekehendak hati secara gegabah, mereka harus tetap mematuhi rambu-rambu hukum yang berlaku. Kesemuanya ini dimaksudkan semata-mata agar dampak yang ditimbulkan tidak meluas dan berakibat fatal.

Tindakan mogok kerja di samping wajib mematuhi ketentuan Undang-Undang Nomor 13 Tahun 2003 tentang Ketenagakerjaan dan Undang-Undang Nomor 22 Tahun 1957 tentang Penyelesaian Perselisihan Perburuhan, para pekerja/buruh juga harus memperhatikan Undang-Undang Nomor 9 Tahun 1998 tentang Kemedekaan Menyampaikan Pendapat di muka umum dan Undang-Undang Nomor 39 Tahun 1999 tentang Hak Azasi Manusia.

Bentuknya jika pekerja/buruh akan melaksanakan mogok kerja di dalam perusahaannya, ia harus memberitahukan kepada pengusaha dan instansi berwenang. Sedangkan jika akan melaksanakan mogok kerja dan unjuk rasa atau demonstrasi di luar perusahaan, selain harus memberitahukan kepada pengusaha dan instansi berwenang yaitu Dinas Tenaga Kerja, juga memberitahukan kepada aparat berwajib setempat.

Beberapa pasal yang mengatur tentang ketentuan pelaksanaan mogok kerja diatur 
dalam pasal 138 sampai dengan pasal 140 , serta pasal 142 ayat 1 , pasal 144, pasal 145 Undang-Undang Nomor 13 Tahun 2003.

Kendatipun hak mogok kerja yang dilakukan oleh undang-undang, sebelum melakukan mogok harus memenuhi syarat-syarat sebagai berikut :

a. Benar-benar sudah diadakan perundingan yang mendalam mengenai pokok- pokok perselisihan antara serikat pekerja dan majikan.

b. Benar-benar permintaan untuk berunding telah ditolak oleh pihak pengusaha.

c. Telah dua kali dalam jangka waktu dua minggu tidak berhasil mengajak pihak lainnya untuk berunding.

Beberapa hal penting yang terkait dengan mogok kerja tidak sah adalah :

a. Mogok kerja yang dilakukan tidak memenuhi ketentuan Pasal 139 dan 140 Undang-Undang Nomor 13 Tahun 2003 adalah mogok kerja tidak sah ( Pasal 142 ayat 1 ).

b. Mogok kerja tidak sah apabila dilakukan :

- Bukan akibat gagalnya perundingan, dan/atau

- Tanpa pemberitahuan kepada pengusaha dan instansi yang bertanggung jawab di bidang ketenagakerjaan, dan/atau

- Dengan pemberitahuan kurang dari tujuh hari kerja sebelum pelaksanaan mogok kerja, dan/atau

- Isi pemberitahuan tidak sesuai dengan ketentuan Pasal 140 ayat 2 huruf $a, b$, c dan d Undang - Undang Nomor 13 Tahun 2003 dan Pasal 3 Keputusan Menteri Tenaga Kerja Nomor Kep232/Men/2003.

c. Mogok kerja tidak sah apabila dilakukan pada perusahaan yang melayani kepentingan umum dan / atau perusahaan yang jenis kegiatannya membahayakan keselamatan jiwa manusia oleh pekerja/buruh yang sedang bertugas ( Pasal 5 Keputusan Menteri Tenaga Kerja Nomor Kep 232/Men/2003).

d. Akibat hukum mogok kerja tidak sah :

- Sebagaimana dimaksud Pasal 3 Keputusan Menteri Tenaga Kerja
Nomor Kep- 232/Men/2003, dikualifikasikan mangkir.

- Sebagaimana dimaksud Pasal 5 Keputusan Menteri Tenaga Kerja Nomor Kep - 232 / Men / 2003, dikualifikasikan mangkir. Jika mengakibatkan hilangnya nyawa manusia yang berhubungan dengan pekerjaan, dikualifikasikan kesalahan berat.

Penutupan perusahaan (lock out) menurut Pasal 1 angka 24 Undang-Undang Nomor 13 Tahun 2003 tentang Ketenagakerjaan adalah tindakan pengusaha untuk menolak pekerja/buruh seluruhnya atau sebagian untuk menjalankan pekerjaan. Dalam melakukan penutupan perusahaan, pengusaha harus mematuhi ketentuan dalam Pasal 146 - 149 Undang-Undang Nomor 13 Tahun 2003.

Sehubungan dengan masalah tersebut, guna menghindari terjadinya mogok atau penutupan perusahaan Pasal 6 Keputusan Menteri Tenaga Kerja Nomor Kep-15 A / Men/ 1994 mengamanatkan bahwa, dalam hal timbul keluh - kesah, perselisihan hubungan industrial dan pemutusan hubungan kerja, pengusaha sedapat mungkin menghindari terjadinya penutupan perusahaan (lock out) dan pekerja sedapat mungkin menghindari terjadinya mogok/unjuk rasa(slowdown).

\section{PENUTUP}

\section{A. Kesimpulan}

1. Hakikat hukum ketenagakerjaan merupakan perlindungan terhadap tenaga kerja, untuk menjamin hakhak dasar pekerja/buruh dan menjamin kesamaan kesempatan serta perlakuan tanpa diskriminasi atas dasar apapun untuk mewujudkan kesejahteraan pekerja/buruh dan keluarganya dengan tetap memperhatikan perkembangan dunia usaha. Sifat perlindungan buruh tenaga kerja untuk mengatur hubungan kerja antara tenaga kerja dan pengusaha dan bersifat privat (perdata). Dalam Undang-Undang Nomor 13 Tahun 2003 tentang ketenagakerjaan mengandung prinsip perlindungan tenaga kerja antara lain 
perlindungan atas hak-hak dalam hubungan kerja, perlindungan keselamatan dan kesehatan kerja, perlindungan khusus bagi pekerja/buruh perempuan, anak penyandang cacat dan perlindungan kesejahteraan dan jaminan sosial. Sedangkan Objek perlindungan tenaga kerja menurut UndangUndang Nomor 13 Tahun 2003 meliputi: a. Perlindungan atas hakhak dalam hubungan kerja. b. Perlindungan atas hak-hak dasar pekerja/buruh untuk berunding dengan pengusaha dan mogok kerja. c. Perlindungan keselamatan dan kesehatan kerja. $d$. Perlindungan khusus bagi pekerja/buruh perempuan, anak dan penyandang cacat. e. Perlindungan tentang upah, kesejahteraan, dan jaminan sosial tenaga kerja dan f. Perlindungan atas hak pemutusan hubungan tenaga kerja.

2. Perlindungan hukum terhadap buruh/pekerja mencakup antara lain:

- keselamatan dan kesehatan kerja,

- perlindungan pekerja atau buruh perempuan, anak dan penyandang cacat.

- perlindungan upah

- perlindungan hak.

\section{B. Saran}

1. Hendaknya para pengusaha dan pekerja sama-sama memahami dan mentaati Hakikat. prinsip-prinsip serta tujuan hukum ketenagakerjaan sebagaimana diatur dalam undang-undang ketenagakerjaan untuk menghindari sengketa ketenagakerjaan dan mewujudkan kesejahteraan buruh/pekerja dan keluarganya.

2. Tujuan perlindungan tenaga kerja adalah untuk menjamin berlangsungnya sistem hubungan kerja secara harmonis serta menjamin hak-hak dasar pekerja dan menjamin kesamaan kesempatan serta tanpa diskriminasi disertai adanya tekanan dari pihak yang kuat kepada pihak yang lemah. Untuk ini pengusaha dan tenaga kerja wajib melaksanakan dan mentaati serta menghormati ketentuan perlindungan tenaga kerja tersebut sesuai peraturan yang berlaku. Pemerintah mengawasi jalannya pelaksanaan aturan ketenagakerjaan agar setiap pihak tidak dirugikan dengan mempertimbangkan perkembangan kemajuan dunia usaha.

\section{DAFTAR PUSTAKA}

Asikin Zainaldkk,Dasar-

dasarHukumPerburuhan, PT

RajaGrafindo Persada,Jakarta, 1997.

Budiono Rachmad Abdul,Hukum Perburuhan

Indonesia, PT RajaGrafindo, Persada, Jakarta, 1997.

KhakimA, Dasar-dasar Hukum Ketenagakerjaan Indonesia, PT Citra Aditya,Bandung, 2009.

Maimun,Hukum Ketenagakerjaan Suatu Pengantar, PTPradnya Paramita, Jakarta, 2007.

Muhammad Abdulkadir, Hukum Perdata Indonesia, , PT Citra Aditya Bakti, Bandung,2014.

\begin{tabular}{lll} 
Husni & \multicolumn{1}{c}{ Lalu, Pengantar } & Hukum \\
& $\begin{array}{l}\text { Ketenagakerjaan } \\
\text { Indonesia,PTRajaGrafindo, Jakarta, }\end{array}$ \\
& 2010. \\
Salim & HS,Pengantar Hukum Perdata \\
& Tertulis(BW), Sinar Grafika,Jakarta, \\
& 2009.
\end{tabular}

Sembiring Joses Jimmy, Legal Officer. Panduan Mengelola Perizinan, Dokumen, Haki, Ketenagakerjaan,\&Masalah Hukum di Perusahaan, Visimedia, Jakarta, 2009.

Subekti R. dan R. Tjitrosudibio, Kitab Undangundang Hukum Perdata, Pradnya Paramita, Jakarta, 1996.

Soekanto Soerjono\& Mamudji Sri, Penelitian Hukum Normatif Suatu Tinjauan Singkat, PT RajaGrafindo Persada, Jakarta, 2004.

Soepomo Imam, Hukum Perburuhan Bagian Pertama Hubungan Kerja, PPAKRI Bhayangkara, Jakarta, 1968. 
Lex Et Societatis Vol. IX/No. 1/Jan-Mar/2021

Subekti, Aneka Perjanjian, Alumni, Bandung, 1982.

Subekti R. dan R. Tjitrosudibio, Kitab Undangundang Hukum Perdata, Pradnya Paramita, Jakarta, 1996.

Trijono Rachmat, Pengantar Hukum Ketenagakerjaan, Papas Sinar Sinanti, Jakarta, 2014.

Tutik Triwulan Titik, Pengantar Hukum Perdata di Indonesia, Prestasi Pustaka Publisher, Jakarta, 2006.

Undang-Undang Serikat Buruh Tahun 2000, Citra Umbara, Bandung, 2000.

Undang-Undang Ketenagakerjaan UU RI NO.13 Tahun 2003, Nusa Media, Bandung, 2010. 